\title{
Alteration of Sulfation of Glycoconjugates, but Not Sulfate Transport and Intracellular Inorganic Sulfate Content in Cystic Fibrosis Airway Epithelial Cells
}

\author{
NIRUPAMA K. MOHAPATRA, PI-WAN CHENG, JOHN C. PARKER, ANTHONY M. PARADISO, \\ JAMES R. YANKASKAS, RICHARD C. BOUCHER, AND THOMAS F. BOAT \\ Departments of Physiology [N.K.M.], Pediatrics [P.W.C., T.F.B.], and Medicine [J.C.P., A.M.P., J.R.Y., \\ R.C.B.J, University of North Carolina, Chapel Hill, North Carolina, 27599-7220
}

\begin{abstract}
The secreted and cell surface high molecular weight glycoconjugates (HMG) generated by primary cultures of airway epithelial cells from cystic fibrosis (CF) patients are oversulfated. To determine whether this abnormality is maintained in transformed CF airway epithelial cells and whether differences in transport or intracellular accumulation of sulfate can explain this alteration, we assessed sulfate metabolism in paired $\mathrm{CF}$ and normal cell lines as well as primary cultures of CF and normal cells. Both 4-acetamido-4'-isothiocyanostilbene-2,2' -disulfonic acid-inhibitable and -resistant $\left[{ }^{35} \mathrm{~S}\right]$ sulfate efflux and influx were identical for each pair of $\mathrm{CF}$ and normal cell lines. Furthermore, cell content of inorganic sulfate was not significantly different in $\mathrm{CF}$ and normal cells. However, compared with primary CF cells that oversulfate HMG transformed CF cells oversulfated cell surface HMG but not HMG released into culture medium. Our results suggest that plasma membrane sulfate transport is not
\end{abstract}

In CF the apical membrane of the epithelial cells is impermeable to $\mathrm{Cl}^{-}$ions (1-3), but displays increased permeability to $\mathrm{Na}^{+}$ions (4). It has now been established that mutations in the CFTR gene result in cAMP-regulated $\mathrm{Cl}^{-}$channel dysfunction (5-7). In addition to the $\mathrm{Cl}^{-}$ion transport abnormality, increased sulfation of tracheobronchial glycoconjugates of CF patients $(8,9)$ has been observed. Furthermore, the severity of lung disease in CF patients appears to correlate with the increased amounts of highly sulfated mucins in airway secretions (10). Although recent studies indicate that CFTR is a $\mathrm{Cl}^{-}$ channel (7), the relationship between defective CFTR and oversulfation of glycoconjugates is not clear. Altered transport of sulfate has been implicated as a pathogenetic mechanism $(11,12)$.

Received May 6, 1994; accepted February 10, 1995.

Correspondence and reprint requests: Thomas F Boat, M.D., Children's Hospital Medical Center, 3333 Burnet Avenue, Cincinnati, OH 45229-3039.

Supported by National Institutes of Health grants HL 42384 and HL 41983. altered in CF airway epithelial cells and the abnormal sulfation of HMG may be due to perturbation in intracellular sulfate activation or transfer of activated sulfate to HMG. The relationship of this abnormality to $\mathrm{CF}$ transmembrane conductance regulator mutations remains to be determined. (Pediatr Res 38: 42-48, 1995)
CF, cystic fibrosis
HMG, high molecular weight glycoconjugates
SITS, 4-acetamido-4' -isothiocyanostilbene-2,2' -disulfonic acid CFTR, cystic fibrosis transmembrane conductance regulator HEPES, $N$-2-hydroxyethylpiperazine- $N$-2-ethanesulfonic acid HPV, human papilloma virus

Abbreviations

Recently, we demonstrated that sulfate transport across the plasma membrane in human airway epithelial cells occurs largely via a SITS-sensitive $\mathrm{Na}^{+}$-insensitive $\mathrm{SO}_{4}{ }^{2-} / \mathrm{Cl}^{-}$exchanger (13). A similar mechanism has been reported in the apical membrane of bovine tracheal epithelial cells and ureteral epithelial cells $(14,15)$. The objective of this study was to compare $\mathrm{SO}_{4^{2-}}$ transport, steady state intracellular sulfate content and glycoconjugate sulfation in normal and CF airway epithelial cells. We used four sets of cultured CF and control airway epithelial cells, including primary cultures, matched cell lines, and CF cells transduced with CFTR CDNA or a reporter gene, in an attempt to elucidate the nature of the $\mathrm{CF}$ sulfate metabolism abnormality.

\section{METHODS}

BEAS S6 and CF/T43 cell lines were derived from normal and CF (CF genotype: homozygous delta F508) airway epithelium, respectively, by transformation with SV-40T $(16,17)$. The cells (passages 10-60) were maintained in KGM (kerati- 
nocyte growth medium, Clonetics, San Diego, CA). BEAS and CF/T43 cells retain many characteristics of epithelial cells and have been used in studies of the vectorial release of IL-6 and fibronectin (18), sulfate transport (13), and chloride conductance (17).

The human airway epithelial cell lines, HNE1, HBE1, CFT1 were generated from nasal, bronchial, and tracheal epithelium donated by two healthy subjects and a CF patient (genotype: homozygous delta F508) using the HPV18 E6/E7 genes (19). Several clones of these cell lines designated $\mathrm{C} 1, \mathrm{C} 2, \mathrm{C} 9$, and PCD2 (for pooled clone whose origin from a single cell was less certain) were studied between passages 10 and 30 . When cultured on collagen matrix supports they developed a stratified epithelium with a columnar basal layer, transepithelial resistance, vectorial transport, and polarization of cell-surface markers (19). Transduced CFT1 clones (20) stably expressing normal CFTR cDNA (CFT1-C9-LCFSN*1) or IL-2 receptor cDNA (CFT1-C9-LISN*1) were also studied. Immunodetection of CFTR by Western blotting in CFT1-C9-LCFSN* 1 cells using rabbit polyclonal antibody was performed as described (21). Primary cultures of airway epithelial cells were generated from excised nasal and bronchial tissues of CF and control donors (22). The HPV18 E6/E7 cell lines and primary cell cultures, were maintained in Ham's F-12 medium supplemented with hormones and growth factors (23). All cells were grown in 35-mm dishes (Corning) for 5-8 d and confluence was determined by microscopic observation. The primary cultures became regionally confluent, whereas all the cell lines reached total confluence before study. The primary cells and the cell lines were characterized and maintained by the Tissue Culture Core Facility of the Cystic Fibrosis Research Center at the University of North Carolina at Chapel Hill.

\section{Chemicals and Reagents}

All reagents were obtained from Sigma Chemical Co. (St. Louis, MO) unless otherwise stated. The two experimental media used in this study were designated as physiologic and Na-gluconate. The physiologic medium contained $132 \mathrm{mM}$ $\mathrm{NaCl}, 1 \mathrm{mM} \mathrm{CaCl}$, $1 \mathrm{mM} \mathrm{MgCl}_{2}, 5 \mathrm{mM} \mathrm{KCl}, 1 \mathrm{mM} \mathrm{KH} \mathrm{PO}_{4}$, $5 \mathrm{mM}$ D-glucose, and $10 \mathrm{mM}$ HEPES. The chloride-free Nagluconate medium contained $140 \mathrm{mM}$ Na-gluconate, $1 \mathrm{mM}$ Ca-gluconate, $1 \mathrm{mM} \mathrm{Mg-gluconate,} 5 \mathrm{mM} \mathrm{K}$-gluconate, and 10 $\mathrm{mM}$ HEPES. Both media were adjusted to $\mathrm{pH} 7.4$ at $25^{\circ} \mathrm{C}$ with Tris. Ice-cold chloride-free sulfate-free Na-gluconate medium was used as a wash solution. A stock solution of $100 \mathrm{mM}$ SITS was prepared in deionized water for each experiment.

\section{Transport Studies}

Efflux. Efflux was carried out as previously reported (13). In short, cells were loaded with ${ }^{35} \mathrm{SO}_{4^{2-}}$ by incubating in $\mathrm{Na}$ gluconate medium containing $8 \mu \mathrm{Ci} / \mathrm{mL}\left[{ }^{35} \mathrm{~S}_{-}-\mathrm{Na}_{2} \mathrm{SO}_{4}\right.$ (sp act, $43 \mathrm{Ci} / \mathrm{mg}$ sulfur, ICN radiochemicals) and $0.3 \mathrm{mM}$ cold $\mathrm{SO}_{4^{2-}}$ for $10 \mathrm{~min}$ at $37^{\circ} \mathrm{C}$. The cells were washed six times with $2 \mathrm{~mL}$ ice-cold wash solution to remove extracellular radioactivity and efflux was initiated by adding $1 \mathrm{~mL}$ sulfate-free physiologic medium at $37^{\circ} \mathrm{C}$. Samples $(0.1 \mathrm{~mL})$ were collected and replaced with an equal volume of physiologic medium at 2-min intervals for $10 \mathrm{~min}$. Then cells were washed three times and lysed with $1 \mathrm{~mL} 0.01 \mathrm{~N} \mathrm{NaOH}$ for $30 \mathrm{~min}$ at room temperature. Total intracellular radioactivity was measured using a Pharmacia scintillation counter. Results are expressed as $\left(\mathrm{dpm}_{\mathrm{t}} / \mathrm{dpm}_{0}\right)$ $\times 100$ where $_{\mathrm{t}}$ is disintegrations/min in cells after $t$-min efflux, and $\mathrm{dpm}_{0}$ is disintegrations/min in the cells at time 0 .

Influx. Influx was measured as $\left[{ }^{35} \mathrm{~S}\right]$ sulfate uptake by the cells washed two times with nonradioactive uptake medium $\left(0.3 \mathrm{mM} \mathrm{Na} \mathrm{NO}_{4}\right)$. Uptake was initiated by adding $1 \mathrm{~mL}$ of medium containing $\left[{ }^{35} \mathrm{~S}\right]$ sulfate $(6 \mu \mathrm{Ci} / \mathrm{mL})$ at a specified temperature for a specified time. Uptake was terminated by rapidly washing the cells six times with $2 \mathrm{~mL}$ of ice-cold wash solution and the cells were lysed with $1 \mathrm{~mL}$ of $0.01 \mathrm{~N} \mathrm{NaOH}$ as described above. The lysate was analyzed for total radioactivity and protein by scintillation counting and Bradford (24) assay, respectively. Data were corrected for $\left[{ }^{35} \mathrm{~S}\right]$ sulfate trapped in the extracellular space by using $\left[{ }^{3} \mathrm{H}\right]$ sucrose $(3-6$ $\mu \mathrm{Ci} / \mathrm{mL}$ ) (sp act, $15 \mathrm{Ci} / \mathrm{mmol}$, American Radiochemicals, St. Louis, MO) as described elsewhere (13).

\section{Determination of Total Intracellular Inorganic Sulfate}

Total intracellular sulfate was determined as previously described (13). Monolayers used for total sulfate measurement were washed six times with ice-cold wash solution and lysed with $1 \mathrm{~mL} 0.01 \mathrm{~N} \mathrm{NaOH}$ (Mallinckrodt, St. Louis, MO) for 30 min at room temperature. The cell extract was lyophilized, resuspended in deionized water, neutralized, and centrifuged in a microcentrifuge. The supernatant was then analyzed for inorganic sulfate by a conductivity detector (Dionex, Atlanta, GA) after separation on an anion exchange column (Dionex Ionpac AS4A) connected to a Varian HPLC. A standard curve was generated and a $\mathrm{Na}_{2} \mathrm{SO}_{4}$ sample of known concentration was injected with each group of samples analyzed. Intracellular sulfate was expressed as nmol/mg protein. The culture medium was analyzed to obtain the extracellular sulfate content.

\section{Radiolabeling of Newly Synthesized HMG}

HMG synthesized by the cultured cells were metabolically labeled as described by Cheng et al. (9) except that $\left[6-{ }^{3} \mathrm{H}\right] \mathrm{glu}-$ cosamine was used instead of $\left[{ }^{3} \mathrm{H}\right]$ serine to label cell surface HMG. Cells were grown on 24-mm diameter Transwell-col dishes (Costar, Cambridge, MA) until confluent in the appropriate medium, then switched to a medium containing Dulbecco's modified Eagle's medium conditioned by $3 \mathrm{~T} 3$ fibroblasts to induce polarization and development of a transepithelial resistance. $\left[6-{ }^{3} \mathrm{H}\right] \mathrm{Glucosamine}(20 \mu \mathrm{Ci} / \mathrm{mL})$ and $\left[{ }^{35} \mathrm{~S}\right]$ sulfate $(100 \mu \mathrm{Ci} / \mathrm{mL})$ were added to the apical and basolateral medium. Media were harvested at $24-\mathrm{h}$ intervals for $48 \mathrm{~h}$. Cell surface HMGs were recovered by incubating the cells with $0.0025 \%$ trypsin (Life Technologies, Inc.) for $30 \mathrm{~min}$ at room temperature. The combined apical and basolateral media for the $48 \mathrm{~h}$ collection as well as the trypsin extract were subjected to Sepharose CL-6B (Pharmacia Biotech Inc., Piscataway, NJ) column chromatography to isolate the HMG which were then quantitated by liquid scintillation counting (9). Multiple clones of HBE1 and CFT1 cell lines were tested individually to avoid the effect of clonal difference. 


\section{Analysis of Data}

All assays were performed in duplicate or triplicate and replicated three to nine times. The results are presented as mean \pm SEM. When several clones of the HBE1 and CFT1 cell lines were analyzed, the results from individual clones did not differ significantly. Therefore these results were analyzed as a group (19). A two-tailed unpaired $t$ test was used to compare the data, with $p<0.05$ considered significant.

\section{RESULTS}

Sulfate efflux. As shown in Fig. 1, 80-99\% of intracellular $\left[{ }^{35}\right.$ S]sulfate moved from transformed (Fig. $1, A$ and $B$ ) or primary cells (Fig. $1 D$ ) into a chloride-containing physiologic medium within $10 \mathrm{~min}$ at $37^{\circ} \mathrm{C}$. At $2 \mathrm{~min}$, total efflux exceeded $90 \%$ from BEAS S6 and CF/T43, 55\% from HBE1-PCD2 and CFT1-C9, and $40 \%$ from primary cells. Although the rate of efflux varied among cell lines and primary cells, there were no significant differences in sulfate efflux rates between any of the paired normal and CF cell cultures at any time point up to ten minutes. Furthermore, CFT1-C9 cell line stably expressing normal CFTR (CFT1-C9-LCFSN*1) or the IL-2 receptor gene (CFT1-C9-LISN*1) demonstrated virtually identical effluxes of $\left[{ }^{35}\right.$ S ]sulfate (Fig. $1 C$ ) which did not differ from the parent cell line (Fig. 1B).
Trans-chloride stimulated efflux from all four sets of cells was inhibited by $0.1 \mathrm{mM}$ of the anion exchange inhibitor SITS at all time points up to $10 \mathrm{~min}$. At $2 \mathrm{~min}, 45-80 \%$ of total efflux was inhibited (Table 1). Although the percent inhibition varied among sets, there was no significant difference between $\mathrm{CF}$ and normal cells of each set whether primary, immortalized, or stably transfected (CFT1-C9-LCFSN*1 and CFT1-C9LISN*1).

Sulfate influx. Fig. $2 A-C$ displays the time course of radioactive sulfate entry into $\mathrm{CF}$ and normal cells bathed in chloride-free, Na-gluconate medium. Uptake of $\left[{ }^{35} \mathrm{~S}\right]$ sulfate at $37^{\circ} \mathrm{C}$ into BEAS S6 and CF/T43 cells was identical when measured at 2, 5, and $10 \mathrm{~min}$. This uptake was almost completely inhibited by $0.1 \mathrm{mM}$ SITS (Fig. 2A). Because uptake was nonlinear at this temperature, studies of HBE1-PCD2, CFT1-C9, and primary normal and CF cell cultures were conducted at a lower temperature $\left(25^{\circ} \mathrm{C}\right)$ and at shorter time intervals. Again, $\mathrm{CF}$ and control uptakes were not different over a 60-s interval (Fig. 2, $B$ and $C$ ). To assess initial rates of uptake, as a reflection of plasma membrane transport, sulfate influx into BEAS S6 and CF/T43 cells (Fig. 3) was compared at $0^{\circ} \mathrm{C}$ over a 45-s time interval. Again no difference was found between BEAS $\mathrm{S} 6$ and $\mathrm{CF} / \mathrm{T} 43$. Furthermore, the initial rate of $\left[{ }^{35}\right.$ S]sulfate uptake into CFT1-C9-LCFSN*1 cells, expressing
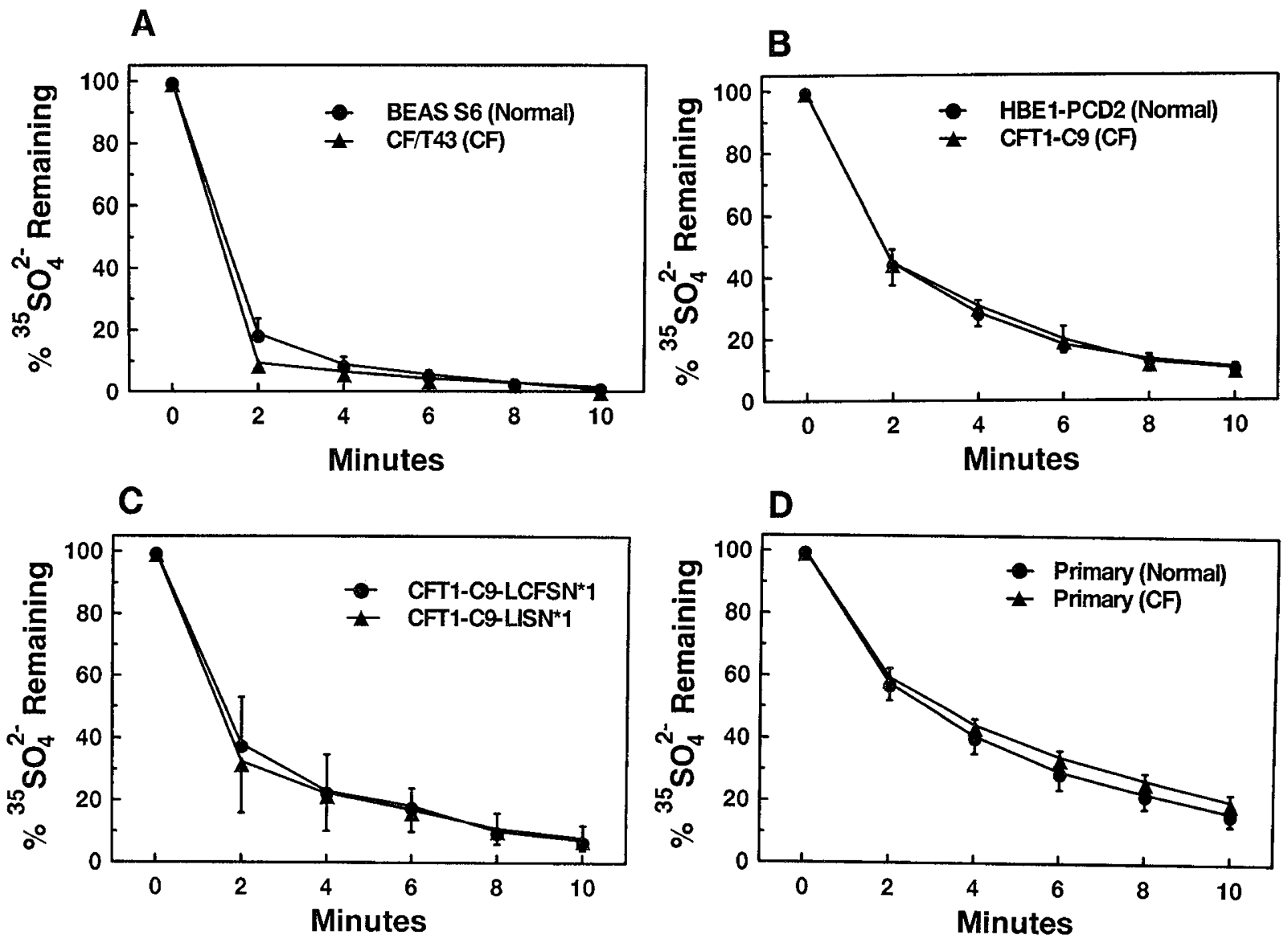

Figure 1. Comparison of trans-chloride-stimulated $\left[{ }^{35} \mathrm{~S}\right]$ sulfate efflux from four paired sets of $\mathrm{CF}$ and control cells. Cells were loaded with $\left[{ }^{35} \mathrm{~S}\right]$ sulfate in Na-gluconate medium at $37^{\circ} \mathrm{C}$. Efflux was initiated by incubating the cells in sulfate-free physiologic medium at $37^{\circ} \mathrm{C}$. Total efflux from normal and CF cells was measured for intervals up to $10 \mathrm{~min}$. Each data point in $A, D$, and $B, C$, is an average (mean \pm SEM) of six and three experiments, respectively. 
Table 1. Inhibition of sulfate efflux by $0.1 \mathrm{mM}$ SITS at $2 \mathrm{~min}$

\begin{tabular}{llcc}
\hline \multicolumn{1}{c}{ Cells } & Origin & $\begin{array}{c}\text { Percent inhibition } \\
\text { (mean } \pm \text { SEM) }\end{array}$ & $p$ \\
\hline BEAS & Normal & $80 \pm 4$ & 0.31 \\
CF/T43 & CF & $73 \pm 7$ & \\
BE1-PCD2 & Normal & $57 \pm 7$ & 0.94 \\
CFT1-C9 & CF & $58 \pm 3$ & \\
CFT1-C9-LCFSN*1 & Normal $^{a}$ & $52 \pm 10$ & 0.45 \\
CFT1-C9-LISN*1 & CF $^{b}$ & $58 \pm 1$ & \\
Primary & Normal & $45 \pm 5$ & 0.98 \\
Primary & CF & $45 \pm 10$ & \\
\hline
\end{tabular}

$n=3$ experiments.

${ }^{a}$ CFT1 cells transduced with normal CFTR cDNA (Corrected).

${ }^{b}$ CFT1 cells transduced with IL-2 receptor cDNA (Reporter).

the CFTR gene, was not different from that of the parent CF cells, in each of four replicate experiments (data not shown).

Total intracellular sulfate content. Total inorganic sulfate in CF and normal transformed and primary cells, maintained in culture medium containing $0.2 \mathrm{mM}$ (KGM) or $0.27 \mathrm{mM}$ (Ham's F-12 + 7X) sulfate and physiologic chloride concentration are presented in Table 2. Intracellular sulfate in BEAS $\mathrm{S} 6$ and CF/T43 cells maintained in medium containing $1.0 \mathrm{mM}$ chloride and $0.1 \mathrm{mM} \mathrm{Na} \mathrm{SO}_{4}$ was also measured because reduced extracellular chloride concentration stimulates intracellular sulfate accumulation, which in turn might enhance a $\mathrm{CF}$ effect. As previously shown (13), intracellular sulfate content of BEAS S6 and CF/T43 was increased in the presence of low extracellular chloride concentration. The cell sulfate contents of BEAS S6 and CF/T43 were not significantly different in physiologic or low chloride medium. The cell sulfate content of the other matched pairs also did not differ.

Sulfation of $\boldsymbol{H M G}$. HMG secreted into the culture medium and associated with the cell surface by cell lines from CF and non-CF sources were analyzed for extent of sulfation by comparing ratios of ${ }^{35} \mathrm{SO}_{4}$ to ${ }^{3} \mathrm{H}(\mathrm{GlcN})$ incorporated into these glycoconjugates. The ${ }^{35} \mathrm{~S} /{ }^{3} \mathrm{H}(\mathrm{GlcN})$ ratios of secreted $\mathrm{HMG}$ did not distinguish normal and $\mathrm{CF}$ cell lines, whether generated by SV40T (BEAS and CF/T43) or by HPV 18 E6/E7 (HBE1 and CFT1) genes. However, the ${ }^{35} \mathrm{~S} /{ }^{3} \mathrm{H}(\mathrm{GlcN})$ ratios for cell surface associated $\mathrm{HMG}$ was increased significantly in both $\mathrm{CF}$ cell lines. In contrast, the ${ }^{35} \mathrm{~S} /{ }^{3} \mathrm{H}(\mathrm{GlcN})$ ratio of secreted and ${ }^{35} \mathrm{~S} /{ }^{3} \mathrm{H}(\mathrm{Ser})$ ratio of cell surface $\mathrm{HMG}$ was increased in primary CF cells, compared with normal cells (Table 3, data from Ref. 9). Expression of normal CFTR cDNA (CFT1-C9LCFSN $^{*} 1$ ) or IL-2 receptor cDNA (CFT1-C9-LISN*1) in CFT1 cells did not significantly alter the ${ }^{35} \mathrm{~S} /{ }^{3} \mathrm{H}(\mathrm{GlcN})$ ratio of the cell surface glycoconjugates. ${ }^{3} \mathrm{H}(\mathrm{GlcN})$ labeling of cell surface $\mathrm{HMG}$ was not different for $\mathrm{CF}$ and normal cell lines indicating that the increased ${ }^{35} \mathrm{~S} /{ }^{3} \mathrm{H}(\mathrm{GlcN})$ ratio was due to increased sulfate incorporation.

\section{DISCUSSION}

Oversulfation of glycoconjugates and mucins in vivo has been a consistent observation in studies of CF respiratory (25) and gastrointestinal (26) secretory products. Secretory components released into medium from CF nasal polyp (27) and

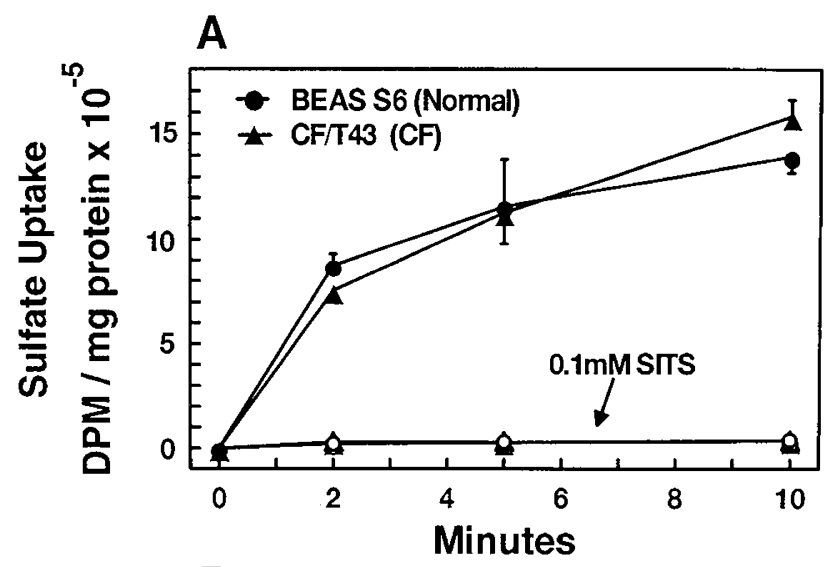

B

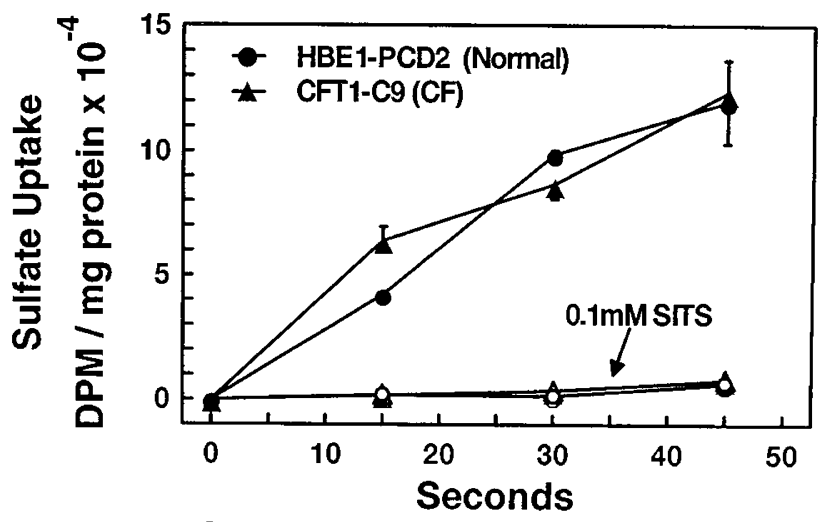

C

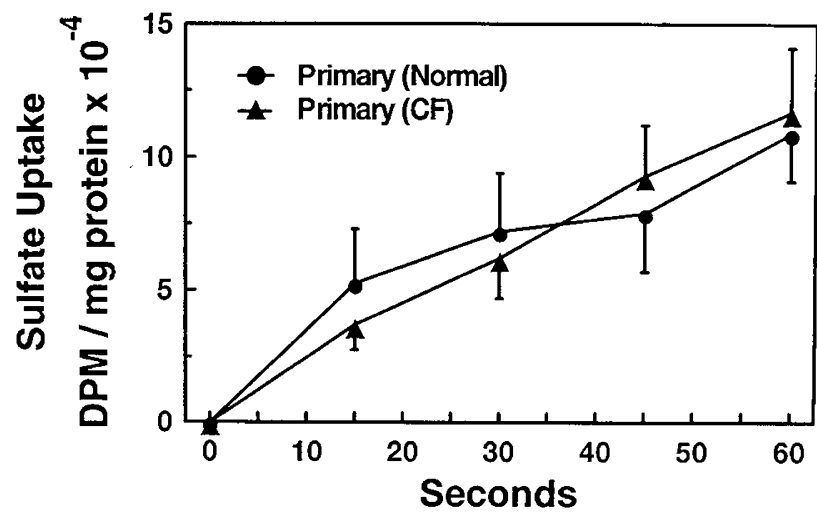

Figure 2. $\left[{ }^{35} \mathrm{~S}\right]$ Sulfate uptake and effect of SITS on uptake for three paired sets of cultured cells: $A, \mathrm{BEAS}$ and CF/T43; $B, \mathrm{HBE1}$-PCD2 and CFT1-C9; $C$, primary normal and $\mathrm{CF}$ cell cultures. Cells were incubated in Na-gluconate medium containing $\left[{ }^{35} \mathrm{~S}\right]-\mathrm{Na}_{2} \mathrm{SO}_{4}$ for $10 \mathrm{~min}$ at $37^{\circ} \mathrm{C}(A)$ and for $45-60 \mathrm{~s}$ at $25^{\circ} \mathrm{C}(B, C)$. Open symbols designate data generated in the presence of $0.1 \mathrm{mM}$ SITS. For $A$ and $B, n=3$, for $C, n=9$ for primary normal and $n=5$ for primary $\mathrm{CF}$.

tracheobronchial explants (28) are similarly oversulfated as assessed by ratios of ${ }^{35} \mathrm{~S} /{ }^{3} \mathrm{H}(\mathrm{GlcN})$ incorporation. $\mathrm{CF}$ nasal epithelial cells in primary culture oversulfate both secreted and cell surface glycoconjugates. The oversulfation in CF cells is due to increased ${ }^{35} \mathrm{SO}_{4}$ incorporation rather than decreased incorporation of ${ }^{3} \mathrm{H}(\mathrm{GlcN})(9)$.

To help distinguish whether these effects are due to CF gene expression or secondary to the intense airway inflammation characteristic of $\mathrm{CF}$, we examined components of the sulfation pathway in immortalized $\mathrm{CF}$ and control airway epithelial 
cells, as well as airway cells in primary culture. Because immortalized cells frequently display phenotypic differences from their parent cells (29), we compared sulfate transport, accumulation and transfer in two paired sets of CF and control respiratory epithelial cells identically immortalized by two different genes, and also assessed sulfate transport and sulfation in one of these CF cell lines which has been transduced with CFTR or the IL-2 receptor cDNAs.

In contrast to primary cultures, CF cell lines do not oversulfate secreted HMG (Table 3). This may reflect selectively reduced capacity to synthesize, sulfate, and/or secrete large glycoconjugates due to cell immortalization. It is also possible that we have observed the waning of persistent effects of chronic in vivo inflammation. However, the oversulfation of cell surface glycoconjugates in the CF cell lines (Table 3) confirms the previous oversulfation reports and suggests that oversulfation may indeed be linked to the CFTR gene mutation. The lack of effect of normal CFTR transduction on HMG sulfation in the CFT1 cell line was surprising, because normal CFTR is expressed in these cells and the chloride conductance abnormality is corrected (20). We speculate that the continuing presence of the delta F508 CFTR in the Golgi and endoplasmic reticulum of the corrected cells may be linked to altered sulfation of HMG. Further investigation using corrected primary and immortalized CF cells is required to resolve this issue.

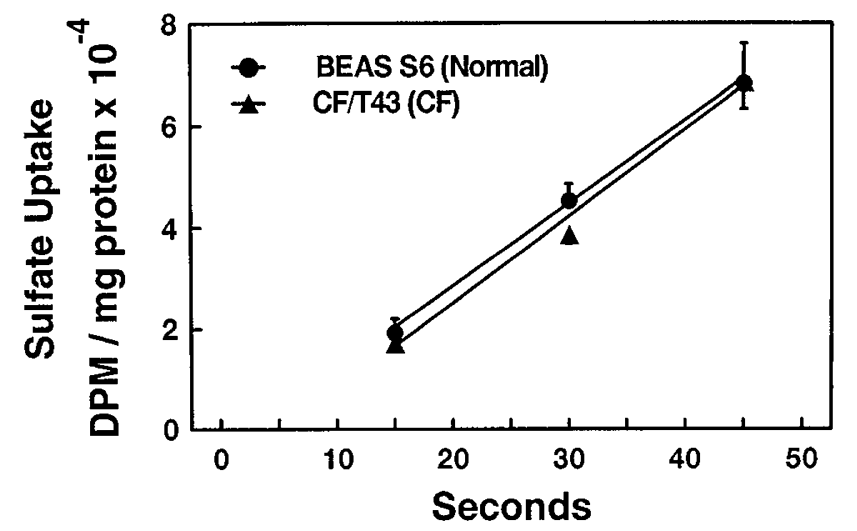

Figure 3. Comparison of initial rates of $\left[{ }^{35} \mathrm{~S}\right]$ sulfate uptake for BEAS and $\mathrm{CF} / \mathrm{T} 43$ cell lines. Cells were incubated in Na-gluconate medium containing $0.3 \mathrm{mM}\left[{ }^{35} \mathrm{~S}\right]-\mathrm{Na}_{2} \mathrm{SO}_{4}$ at $0^{\circ} \mathrm{C}$ for $45 \mathrm{~s}$. Each data point is an average of five experiments \pm SEM.
Our study focused on the transport of inorganic sulfate across the plasma membrane as a first and possible rate limiting step in the sulfation process. The sulfate transport data showed no evidence of altered SITS-sensitive (anion-exchange mediated) or SITS-insensitive $\mathrm{SO}_{4^{2-}}$ efflux or influx in either immortalized or primary $\mathrm{CF}$ cells. The initial rates of $\mathrm{SO}_{4^{2-}}$ uptake, which directly reflect plasma membrane transport, did not differ in the CF cell lines. We previously reported that, unlike chloride conductance (31), SITS-sensitive anion exchange, the predominant sulfate transport pathway in respiratory epithelial cells, is not a cAMP dependent mechanism (13), and therefore would not be expected to be affected in CF. Furthermore, in our present investigation, sulfate efflux was identical in a CF cell line expressing CFTR when compared with the same cell line expressing the reporter gene. These observations differ from the reports of increased $\mathrm{SO}_{4^{2-}}$ transport in CF skin fibroblasts (11) and decreased transport in a CF pancreatic tumor cell line (12), and may reflect tissue differences.

Sulfate transport via the exchanger is regulated by extracellular and intracellular $\mathrm{Cl}^{-}$concentration and $\mathrm{pH}(13,30)$. Chloride concentrations (31) and intracellular pH (32) are not different in CF airway cells. Therefore, to the extent that sulfate distribution is linked to that of $\mathrm{Cl}^{-}$and $\mathrm{H}^{+}$ions, the intracellular sulfate content contributed by the exchanger was not expected to be different. However, the intracellular sulfate pool is derived not only from external sulfate but also from oxidative catabolism of sulfur-containing amino acids. Consistent with similar plasma membrane transport, inorganic sulfate content in CF airway cells is not different, suggesting that transport and accumulation of intracellular sulfate are unlikely contributors to the enhanced rate of HMG sulfation in CF cells. Thus, the CF sulfation abnormality most likely reflects CFselective changes in downstream sulfate metabolism pathways, namely sulfate activation (33), active sulfate (PAPS) transport into the Golgi (34), or sulfotransferase catalyzed sulfation of glycoconjugates (35). A recent report claims that CF respiratory epithelial cells display defective acidification of endosomal compartments and speculate that elevated trans-Golgi $\mathrm{pH}$ may enhance sulfotransferase activity (36). However, subsequent work has failed to support the claim that defective CFTR function would result in endosomal $\mathrm{pH}$ changes (37). Furthermore, the observation of acidification of CF pancreatic tumor

Table 2. Steady-state intracellular inorganic sulfate content

\begin{tabular}{|c|c|c|c|c|c|c|}
\hline Cells & Origin & $\begin{array}{c}{\left[\mathrm{Cl}^{-}\right]_{e}^{*}} \\
(\mathrm{mM})\end{array}$ & $\begin{array}{c}{\left[\mathrm{SO}_{4}{ }^{2-}\right]_{\mathrm{e}}} \\
(\mathrm{mM})\end{array}$ & $\begin{array}{c}{\left[\mathrm{SO}_{4}{ }^{2-}\right]_{\mathrm{i}} \dagger} \\
(\mathrm{nmol} / \mathrm{mg} \text { protein })\end{array}$ & $n$ & $p$ \\
\hline BEAS & Normal & 140 & 0.2 & $3.1 \pm 0.8$ & 4 & 0.97 \\
\hline $\mathrm{CF} / \mathrm{T} 43$ & $\mathrm{CF}$ & 140 & 0.2 & $3.1 \pm 1.1$ & 4 & \\
\hline BEAS & Normal & 1 & 0.1 & $10.6 \pm 0.6$ & 5 & 0.27 \\
\hline $\mathrm{CF} / \mathrm{T} 43$ & $\mathrm{CF}$ & 1 & 0.1 & $12.8 \pm 1.2$ & 5 & \\
\hline HNE1-C4 & Normal & 140 & 0.3 & $3.3 \pm 0.4$ & 6 & 0.71 \\
\hline CFT1-C1 & $\mathrm{CF}$ & 140 & 0.3 & $3.0 \pm 0.7$ & 6 & \\
\hline Primary & Normal & 140 & 0.3 & $4.6 \pm 0.8$ & 10 & 0.61 \\
\hline Primary & $\mathrm{CF}$ & 140 & 0.3 & $5.3 \pm 1.1$ & 8 & \\
\hline
\end{tabular}

Note: Inorganic sulfate of cell lysates and culture media were determined by HPLC (13). The extracellular chloride concentration was calculated.

$* \mathrm{e}=$ extracellular.

$\dagger \mathrm{i}=$ intracellular. 
Table 3. ${ }^{35} S{ }^{\beta} H(G l c N)$ ratios for secreted and cell-surface HMG under basal culture conditions

\begin{tabular}{|c|c|c|c|c|c|}
\hline \multirow[b]{3}{*}{ Cells } & \multicolumn{5}{|c|}{${ }^{35} \mathrm{~S} /{ }^{3} \mathrm{H}(\mathrm{GlcN})$ ratios } \\
\hline & \multicolumn{3}{|c|}{ Secreted HMG } & \multicolumn{2}{|c|}{ Cell surface HMG } \\
\hline & $n$ & Mean \pm SEM & $p$ & Mean \pm SEM & $p$ \\
\hline $\begin{array}{l}\text { Primary normal } \\
\text { Primary CF }\end{array}$ & $\underline{-}^{a}$ & $\begin{array}{l}0.14 \pm 0.01 \\
0.28 \pm 0.03\end{array}$ & $<0.001$ & $\begin{array}{l}0.28 \pm 0.09^{b} \\
0.85 \pm 0.12^{b}\end{array}$ & $<0.005$ \\
\hline $\begin{array}{l}\text { BEAS } \\
\text { CF/T43 }\end{array}$ & $\begin{array}{l}9 \\
9\end{array}$ & $\begin{array}{l}0.52 \pm 0.06 \\
0.57 \pm 0.07\end{array}$ & 0.62 & $\begin{array}{l}0.48 \pm 0.07 \\
0.94 \pm 0.15\end{array}$ & 0.012 \\
\hline $\begin{array}{l}\text { HBE1(PCD2,C2,C9 })^{c} \\
\text { CFT1 }(\mathrm{C} 1, \mathrm{C} 2, \mathrm{C} 9)^{c}\end{array}$ & $\begin{array}{l}7 \\
6\end{array}$ & $\begin{array}{l}0.22 \pm 0.06 \\
0.26 \pm 0.05\end{array}$ & 0.93 & $\begin{array}{l}0.46 \pm 0.07 \\
0.76 \pm 0.07\end{array}$ & 0.024 \\
\hline CFT1-C9-LCFSN*1 & 4 & $0.3 \pm 0.03$ & $\begin{array}{l}0.33^{d} \\
0.30^{e}\end{array}$ & $0.7 \pm 0.11$ & $\begin{array}{l}0.45 \\
0.60^{d}\end{array}$ \\
\hline CFT1-C9-LISN*1 & 4 & $0.36 \pm 0.05$ & & $0.59 \pm 0.13$ & \\
\hline CFT1-C9 & 4 & $0.37 \pm 0.06$ & $0.88^{f}$ & $0.8 \pm 0.18$ & $0.33^{e}$ \\
\hline
\end{tabular}

${ }^{a}$ Reported previously (9).

${ }^{b}{ }^{35} \mathrm{~S} /{ }^{3} \mathrm{H}$ (serine) ratios were analyzed for cell surface $\mathrm{HMG}$.

${ }^{c}$ The results for the three different clones of each cell line did not differ significantly, were averaged.

${ }^{d} p$ values for comparison of CFT1-C9-LCFSN ${ }^{*} 1$ and CFT1-C9-LISN*1.

${ }^{e} p$ values for comparison of CFT1-C9-LCFSN*1 and CFT1-C9.

${ }^{f} p$ values for comparison of CFT1-C9-LISN ${ }^{*} 1$ and CFT1-C9.

cells (38) has not been substantiated for cultured CF respiratory epithelial cells (32). Although oversulfation of CF airway glycoconjugates has been observed in vivo and in vitro, it has been technically difficult to identify the cause of oversulfation and the specific class of oversulfated glycoconjugates. Thus, the pathogenesis of increased sulfation in $\mathrm{CF}$ remains elusive and will require further examination.

In summary, we have confirmed the enhanced sulfation of cell surface HMG by CF airway epithelial cells, even after these cells have been immortalized. In addition, we have demonstrated that inorganic sulfate transport and accumulation are not perturbed in these CF cells, directing future attention to sulfate activation and transfer as the likely steps at which these cells differ from control cells. The potential for enhanced sulfation to adversely affect the properties of secreted and cell surface glycoconjugates of airway cells (9) suggests that future exploration of these steps could contribute important information relevant to $C F$ lung pathogenesis.

Acknowledgments. We thank Dr. Elmer Price for reviewing the manuscript and John Singleton, USDA, NCSU, for assistance in inorganic sulfate measurement. In particular, we wish to acknowledge the important contribution of the late Dr. John C. Parker in the conceptual design and interpretation of these studies.

\section{REFERENCES}

1. Quinton PM 1983 Chloride impermeability in cystic fibrosis. Nature 301:421-422

2. Knowles MR, Stutts MJ, Spock A, Fischer N, Gatzy JT, Boucher RC 1983 Abnormal ion permeation through cystic fibrosis respiratory epithelium. Science 221:1067-1070 3. Stutts MJ, Cotton CU, Yankaskas JR, Cheng E, Knowles MR, Gatzy JT, Boucher RC 1985 Chloride uptake into cultured airway epithelial cells from cystic fibrosis patients and normal individuals. Proc Natl Acad Sci USA 82:6677-6682

4. Boucher RC, Stutts MJ, Knowles MR, Cantley L, Gatzy JT $1986 \mathrm{Na}^{+}$transport in cystic fibrosis respiratory epithelia. J Clin Invest 78:1245-1252

5. Riordan JR, Rommens JM, Kerem B-S, Alon N, Rozmahel R, Grzelczak Z, Zielenski J, Lok S, Plavsic N, Ckou J-L, Drumm ML, Ianuzzi MC, Collins FS, Tsui L-C 1989 Identification of the cystic fibrosis gene: Cloning and characterization of complementary DNA. Science 245:1066-1072

6. Kerem B-S, Zielenski J, Markiewicz D, Bozon D, Gazit E, Yahav J, Kennedy D, Riordan JR, Collins FS, Rommens JM, Tsui L-C 1990 Identification of mutations in regions corresponding to the two putative nucleotide (ATP) binding folds of the cystic fibrosis gene. Proc Natl Acad Sci USA 87:8447-8451

7. Anderson MP, Gregory RJ, Thompson S, Souza DW, Paul S, Mulligan RC, Smith AE Welsh MJ 1991 Demonstration that CFTR is a chloride channel by alteration of its anion selectivity. Science 253:202-205

8. Boat TF, Cheng P-W 1980 Biochemistry of airway mucus secretions. Fed Proc 39:3067-3074

9. Cheng P-W, Boat TF, Cranfill K, Yankaskas JR, Boucher RC 1989 Increased sulfation of glycoconjugates by cultured nasal epithelial cells from patients with cystic fibrosis. $J$ Clin Invest 84:68-72

10. Chace KV, Leahy DS, Martin R, Carubelli R, Flux M, Sachdev GP 1983 Respiratory mucous secretions in patients with cystic fibrosis: Relationship between levels of highly sulfated mucin component and severity of the disease. Clin Chim Acta 132:143-155

11. Elgavish A, Meezan E 1988 Increased sulfate uptake in skin fibroblasts isolated from cystic fibrosis patients. Biochem Biophys Res Commun 152:99-106

12. Elgavish A, Meezan E 1992 Altered sulfate transport via anion exchange in CFPAC is corrected by retrovirus mediated CFTR gene transfer. Am J Physiol 263 32:C176C186

13. Mohapatra NK, Cheng P-W, Parker JC, Paradiso AM, Yankaskas JR, Boucher RC, Boat TF 1993 Sulfate concentration and transport in human bronchial epithelial cells. Am J Physiol 264 33:C1231-C1237

14. Elgavish A, DiBona DR, Norton P, Meezan E 1987 Sulfate uptake in apical membrane vesicles isolated from tracheal epithelium. Am J Physiol 253:C416-C425

15. Elgavish A, Wille JJ, Rahemtulla F, LaJoyce D 1991 Carrier-mediated sulfate transport in human ureteral epithelial cells cultured in serum-free medium. Am J Physiol 261:C916-C926

16. Reddel JR, Ke Y, Gerwin BI, McMenamin MG, Lechner JF, Su RT, Brash DE, Park J, Rhim JS, Harris CC 1988 Transformation of human bronchial epithelial cells by infection with SV40 or adenovirus-12 SV40 hybrid virus, or transfection via strontium phosphate coprecipitation with a plasmid containing SV40 early region genes. Cancer Res 48:1904-1909

17. Jetten AM, Yankaskas JR, Stutts MJ, Willumsen NJ, Boucher RC 1989 Persistence of abnormal chloride conductance regulation in transformed cystic fibrosis epithelia. Science 244:1472-1475

18. Noah TL, Paradiso AM, Madden MC, McKinnon KP, Devlin RB 1991 The response of human bronchial epithelial cell line to histamine: intracellular calcium changes and extracellular release of inflammatory mediators. Am J Respir Cell Mol Biol 5:484492

19. Yankaskas JR, Haizlip JE, Conrad M, Koval D, Lazarowski E, Paradiso AM, Rinehart, Jr CA, Sarkadi B, Schlegel R, Boucher RC 1993 Papilloma virus immortalized tracheal epithelial cells retain a well-differentiated phenotype. Am J Physiol 264:C1219-C1230

20. Olsen JC, Johnson LG, Stutts MJ, Sarkadi B, Yankaskas JR, Swanstrom R, Boucher RC 1992 Correction of apical membrane chloride permeability defect in polarized cystic fibrosis airway epithelia following retroviral-mediated gene transfer. Hum Gene Ther 3:253-266

21. Sarkadi B, Bauzon DD, Huckle W, Earp HS, Berry A, Suchindran H, Price E, Olsen J, Boucher RC, and Scarborough GA 1992 Biochemical characterization of the CFTR in normal and cystic fibrosis epithelial cells. J Biol Chem 267:2087-2095

22. Yankaskas JR, Cotton CU, Knowles MR, Gatzy JT Boucher RC 1985 Culture of human nasal epithelial cells on collagen matrix supports. Am Rev Respir Dis 132:1281-1287

23. Clarke LL, Paradiso AM, Mason SJ, Boucher RC 1992 Effects of bradykinin on $\mathrm{Na}^{+}$ and $\mathrm{Cl}^{-}$transport in human nasal epithelium. Am J Physiol 262:C644-C55 
24. Bradford MM 1976 A rapid and sensitive method for the quantitation of microgram quantities of protein utilizing the principle of protein-dye binding. Anal Biochem 72:248-254

25. Boat TF, Cheng P-W, Iyer R, Carlson DM, Poleny I 1976 Human respiratory tract secretions: Mucous glycoproteins of nonpurulent tracheobronchial secretions, and sputum of patients with bronchitis and cystic fibrosis. Arch Biochem Biophys 177:95-104

26. Wesley A, Forstner J, Gureshi R, Mantle M, Forstner G 1983 Human intestinal mucin in cystic fibrosis. Pediatr Res 17:65-69

27. Boat TF, Kleinerman JI, Carlson DM, Maloney WH, Matthews LW 1974 Human respiratory tract secretions: Mucous glycoproteins secreted by cultured nasal polyp epithelium from subjects with allergic rhinitis and cystic fibrosis. Am Rev Respir Dis 110:428-421

28. Frates RC, Kaizu TT, Last JA 1983 Mucous glycoproteins secreted by respiratory epithelial tissue from cystic fibrosis patients. Pediatr Res 17:30-34

29. Schwab UE, Wold AE, Carson JL, Leigh MW, Cheng P-W, Gilligan PH, Boat TF 1993 Increased adherence of Staphylococcus aureus from cystic fibrosis lungs to airway epithelial cells. Am Rev Respir Dis 148:365-369

30. Elgavish A, and Meezan E 1989 Sulfate transport in human lung fibroblast (IMR-90): Effect of $\mathrm{pH}$ and anions. Am J Physiol 256:C486-C494
31. Willumsen NJ, Davis CW, Boucher RC 1989 Cellular $\mathrm{Cl}^{-}$transport in cultured cystic fibrosis airway epithelium. Am J Physiol 256:C1045-C1053

32. Paradiso A 1992 Identification of $\mathrm{Na}^{+}-\mathrm{H}^{+}$exchange in human normal and cystic fibrotic ciliated airway epithelium. Am J Physiol 262:L757-L764

33. Mulder GJ 1981 Sulfation of Drugs and Related Compounds. CRC Press, Boca Raton, FL, pp 31-52

34. Hirschberg CB, Snider MD 1987 Topography of glycosylation in the rough endoplasmic reticulum and Golgi apparatus. Annu Rev Biochem 56:63-87

35. Segel IH, Ronosto F, Seubert PA 1987 Sulfur activating enzymes. Methods Enzymol 143:334-349

36. Barasch J, Kiss B, Prince A, Saiman L, Gruenert D, Al-Awquati, Q 1991 Defective acidification of intracellular organelles in cystic fibrosis. Nature 352:70-73

37. Lukacs GL, Chang X-B, Kartner N, Rotstein OD, Riordan JR, Grinstein S 1992 The cystic fibrosis transmembrane regulator is present and functional in endosomes. J Biol Chem 267:14568-14572

38. Elgavish A 1991 High intracellular pH in CFPAC: a pancreas cell line from a patient with cystic fibrosis is lowered by retrovirus-mediated CFTR gene transfer. Biochem Biophys Res Commun 180:342-348 